\title{
Changes in leaf water potential and photosynthesis of Bauhinia forficata Link under water deficit and after rehydration
}

\author{
Rodrigo Fazani Esteves Sanches ${ }^{1}$ and Emerson Alves da Silva ${ }^{2,3}$
}

Received: 21.08.2012; accepted: 22.02 .2013

\begin{abstract}
Changes in leaf water potential and photosynthesis of Bauhinia forficata Link under water deficit and after rehydration). To evaluate the influence of different intensities of water deficit and rehydration on water relations and gas exchanges of Bauhinia forficata Link, plants were grown in a greenhouse for three months under the following water regimes: daily watered (control) and watered every 7 (7D) and 15 days (15D) returning to daily watering on 7D and 15D treatments at 75 days of the experiment. Aiming to evaluate short-term responses to re-hydration, plants of 7D and 15D treatments were re-watered 2 days before measurements and sampling was carried out at the $45^{\text {th }}$ day of experiment. At fortnightly intervals $\left(15,30,45,60,75\right.$, and 90 days) soil moisture (Usoil), leaf water potential ( $\left.\Psi_{w f}\right)$, photosynthesis in response to photosynthetically active radiation $(A \times$ PPFD) to obtain the maximum net photosynthesis $(A \max )$, and light saturation point (PARsat) were evaluated. The water deficit has affected water relations and photosynthesis with the lowest values observed in the treatments $\mathrm{U}_{\text {soil }} 7 \mathrm{D}$, and $15 \mathrm{D}$ respectively, coinciding with the lowest $\Psi_{w f}$ and Amax. Changes in PARsat in response to water deficit were observed showing mean values of 665,275 and $254 \mu$ mol photons $\mathrm{m}^{-2} \mathrm{~s}^{-1}$ in control, 7D and $15 \mathrm{D}$ respectively. The return of daily watering after 75 days of experiment, promoted the recovery of $A \max (7.8$ and $9.6 \mu$ mol $\mathrm{CO}_{2} \mathrm{~m}^{-2} \mathrm{~s}^{-1}$ ) and PARsat (588 and $643 \mu \mathrm{mol}$ photons $\mathrm{m}^{-2} \mathrm{~s}^{-1}$ ) in 7D and 15D respectively with values higher than control plants $\left(4.7 \mu \mathrm{mol} \mathrm{CO} \mathrm{m}^{-2} \mathrm{~s}^{-1}\right.$ and $631 \mu \mathrm{mol}$ photons $\left.\mathrm{m}^{-2} \mathrm{~s}^{-1}\right)$, suggesting a strong dependence of photosynthesis of Bauhinia forficata to the soil water availability.
\end{abstract}

Key words: Brazilian Orchid-tree, drought tolerance, plasticity

RESUMO - (Alterações no potencial hídrico foliar e fotossíntese de Bauhinia forficata Link sob déficit hídrico e após reidratação). Para avaliar a influência de déficits hídricos de diferentes intensidades e da reidratação nas relações hídricas e trocas gasosas, plantas de Bauhinia forficata Link foram cultivadas em casa de vegetação durante três meses e submetidas aos regimes de regas diárias (controle) e regas a cada 7 (7D) e 15 dias (15D) retornando as regas diárias nos regimes 7D e $15 \mathrm{D}$ aos 75 dias de experimento. Com o objetivo de avaliar respostas de curto prazo à re-hidratação, plantas dos tratamentos $7 \mathrm{D}$ e $15 \mathrm{D}$ foram re-irrigadas 2 dias antes das medidas realizadas no $45^{\circ}$ de experimento. Em intervalos quinzenais (15, 30, 45, 60, 75 e 90 dias) foram avaliadas a umidade do solo (Usolo), potencial hídrico foliar ( $\Psi w f)$, a fotossíntese em resposta a radiação fotossinteticamente ativa $(A \times$ PPFD) para obtenção da fotossíntese máxima $(A \max )$ e da radiação fotossinteticamente ativa na saturação (PARsat). O déficit hídrico afetou as relações hídricas e fotossíntese, sendo que os menores valores de Usolo observados nos tratamentos 7D e 15D respectivamente, coincidiram com os menores $\Psi_{w f} \mathrm{e}$ Amax. Alterações nos PARsat em

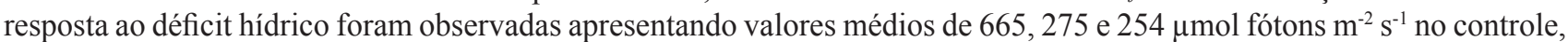
$7 \mathrm{D}$ e $15 \mathrm{D}$, respectivamente. O retorno das regas diárias após 75 dias de experimento promoveu a recuperação de $A \max (7,8$ e 9,6 $\left.\mu \mathrm{mol} \mathrm{CO} \mathrm{m}^{-2} \mathrm{~s}^{-1}\right)$ e dos PARsat $\left(588\right.$ e $643 \mu \mathrm{mol}$ fótons $\left.\mathrm{m}^{-2} \mathrm{~s}^{-1}\right)$ das plantas 7D e 15D, respectivamente, aos 90 dias, com valores maiores daqueles observados nas plantas controle $\left(4,7 \mu \mathrm{mol} \mathrm{CO} \mathrm{m}^{-2} \mathrm{~s}^{-1}\right.$ e $631 \mu \mathrm{mol}$ fótons $\left.\mathrm{m}^{-2} \mathrm{~s}^{-1}\right)$, sugerindo forte dependência da fotossíntese de Bauhinia forficata à disponibilidade hídrica no solo.

Palavras-chave: pata-de-vaca, plasticidade, tolerância a seca

\section{INTRODUCTION}

The distribution of plants on Earth's surface is controlled basically by two abiotic factors, air temperature and water availability in soil. Since air temperature allows, the amount and distribution of rain becomes the major limiting factor to plant development (Kramer \& Boyer 1995). This ecological importance of water is a result of its physiological importance, being the only way by which an environmental factor

1. Programa de Pós-graduação em Fisiologia e Bioquímica de Plantas, Universidade de São Paulo, ESALQ, Av. Pádua Dias, 11, 13418-900 Piracicaba, SP, Brasil

2. Instituto de Botânica, Núcleo de Pesquisa em Fisiologia e Bioquímica, Av. Miguel Stéfano 3687, 04301-902 São Paulo, SP, Brasil

3. Corresponding author: easilva@ibot.sp.gov.br 
such as water can affect the plant growth is influencing physiological processes (Koslowski \& Pallardy 1997).

Due to the increase of carbon dioxide in atmosphere, which leads to an increase in air temperature, it is considered that there will raise the atmospheric demand for water and, on many regions, with higher occurrence, frequency, intensity and distribution of droughts. The climate change models show an high frequency of rainfall separated by long dry periods (Dore 2005). In this scenario, the projected climate changes for the coming years due to global warming, make studies on water use by native species critical, not only to preserve ecosystems, but also to define strategies for recovery of degraded areas, since the establishment of the species is a critical step to the recovery of these areas. Thus, among the environmental factors, water deficiency stands out as an adverse factor to the growth and crop production making it essential for studies to address the issue.

Water deficiency has been considered as one of the main factors limiting the productivity, both agricultural and natural ecosystems. In nature, the intensity and distribution of rainfall determine the water regime, from influencing the growth and productivity of individuals, to the distribution of populations and the biodiversity of ecosystems. The water deficit caused by drought is established when the water absorption from root system cannot meet the demands of the plant (Fan et al. 2006). Among the main demands are photosynthesis and transpiration, two essential processes for plant growth. Before the water deficit has been established, roots have to sense the dry soil and transmit this information to shoot, which creates an integrated response of the plant allowing its survival until the water availability increases. This communication is done by several means in addition to the reduction of the upward flow of water (Davies \& Zhang 1991).

The main physiological processes that affectes plants under water deficit, are stomatal conductance, mesophyll photosynthesis and, by extension, their growth. However, such effects depend of the species studied as well as the intensity and duration of the water deficit rate (Chaves \& Pereira 1992).

Stomatal closure is in fact one of the first lines of defense against water deficits, since it is a fast and flexible process on relation to other alternatives, such as changes in the life cycle, root growth or leaf area, which constitute long term responses. The stomatal closure reduces water loss by the plant, but at the same time decreases the entry of $\mathrm{CO}_{2}$ from the atmosphere to the substomatal cavity, influencing the carbon assimilation (Chaves 1991).

The species Bauhinia forficata Link presents broad neotropical distribution being found in Argentina, Bolivia, Paraguay, Uruguay and Brazil (Fortunato 1986), thus occurring in different biomes. Moreover, it is recommended for projects of recovery of degraded areas, being a good model for studies on plant responses to environmental stresses such as water deficit.

Due to the wide distribution, we hypothesized that of $B$. forficata presents a high tolerance to drought allowing their occurrence and survival under different environments, mainly under water deficit conditions. Furthermore, since photosynthetic capacity plays an important role on plant establishment and growth, little is known about the effects of water stress in the photosynthesis of this species, considering that it is widely recommended for recovery of degraded areas.

This work aimed at evaluates changes in photosynthesis of Bauhinia forficata in response to different intensities of water deficits and after recovery by hydratation.

\section{Material and methods}

Plant material and growing conditions - plants of B. forficata with 6 months of age were obtained in the nursery BioFlora Forest Restoration in the city of Piracicaba, São Paulo State, Brazil and transplanted into individual pots of $20 \mathrm{~L}$, containing organic soil substrate (Tropstrato, $\mathrm{HT}^{\circledR}$ ). Plants were daily watered and received Clark nutrient solution (Clark 1975), once a week until beginning of the experiment. After, nutrient solution was applied in fortnightly intervals. The pot-plant sets were maintained in a greenhouse at the Núcleo de Pesquisa em Fisiologia e Bioquímica do Instituto de Botânica (IBt/SMA/SP) throughout the experimental period. After three mouths the different water regimes were imposed on plants in the following treatments: daily watered plants (control), watered every 7 days (7D) and every 15 days (15D) returning to daily water regimes at $75^{\text {th }}$ days of the experiment. Aiming to evaluate short-term responses to re-hydration, plants of 7D and 15D treatments were re-watered 2 days before measurements and sampling carried at $45^{\text {th }}$ days of the experiment. In each treatment of watering regimes water was provided until pot saturation aiming to elevate soil moisture close to the field capacity in pots. 
The watering frequencies of 7 and 15 days were defined previously on an pilot experiment where water supply to 10 potted plants distinct from that used in the main experiment. was totally suspended and leaf water potential was measured aiming to ensure the establishment of water deficit and avoid plant death during the main experiment.

At fortnightly intervals $(15,30,45,60,75$ and, 90 days) soil moisture $\left(\mathrm{U}_{\text {soil }}\right)$, leaf water potential $\left(\Psi_{w f}\right)$ at predawn, photosynthesis in response to photosynthetic photon flux density $(A \times$ PPFD) to obtain the maximum net photosynthesis $\left(A_{\max }\right)$ and light saturation point (PARsat) were evaluated.

During the experiment, the temperature $\left({ }^{\circ} \mathrm{C}\right)$, relative humidity $(\mathrm{RH}, \%)$ and the photosynthetic photon flux density (PPFD, $\mu$ mol photons $\mathrm{m}^{-2} \mathrm{~s}^{-1}$ ) were monitored inside the greenhouse using a temperature/humidity sensor (Li-1400-140, Li-Cor Nebraska, USA) and a quantum sensor (Li- 190SA, Li-Cor - Nebraska, USA) respectively. The sensors were connected to a datalogger (Li-1400, Li-Cor Nebraska, USA), which was configured to perform the measurements at intervals of 10 minutes, calculating daily means for each parameter evaluated.

Ecophysiological Evaluations - Soil moisture (Usoil, \%) was measured by time domain reflectometry, using a sensor model ML2 Delta-X-T Devices (ThetaProbe, Cambridge, UK). In order to quantify the intensity of water deficit imposed to the plants in the different treatments, leaf water potential $\left(\Psi_{w f}, \mathrm{MPa}\right)$ at predaw ( 5 and $6 \mathrm{~h}$ ) were measured in the $2^{\text {nd }}$ fully expanded leaf from the apex of each plant using a pressure pump type Scholander, Model 1000 (PMS Instrument Co., UTAH, USA). We performed instantaneous measurements of net carbon assimilation rates $(A$, $\left.\mu \mathrm{mol} \mathrm{CO} \mathrm{m}^{-2} \mathrm{~s}^{-1}\right)$, stomatal conductance $\left(\mathrm{g}_{\mathrm{s}}, \mathrm{mol} \mathrm{m}^{-2}\right.$ $\left.\mathrm{s}^{-1}\right)$ and transpiration $\left(E, \mathrm{nmol} \mathrm{m} \mathrm{m}^{-2} \mathrm{~s}^{-1}\right)$ in response to photosynthetically active radiation (PAR, $\mu \mathrm{mol}$ photons $\mathrm{m}^{-2} \mathrm{~s}^{-1}$ ), curves $A \times$ PPFD. From these curves we defined the light point saturation (PARsat, $\mu \mathrm{mol}$ photons $\mathrm{m}^{-2} \mathrm{~s}^{-1}$ ) and maximum net photosynthesis (Amax, $\mu$ mol photons $\mathrm{m}^{-2} \mathrm{~s}^{-1}$ ) according to model proposed by Long \& Hällgren (1993). Measurements were carried using an infrared gas analyzer (IRGA) model Li-6400 (Li-Cor - Nebraska, USA) in open system, between 8 to $11 \mathrm{~h}$. Curves $A \times$ PPFD were performed in the $3^{\text {rd }}$ fully expand leaf from the apex of each plant, with a concentration of $380 \mathrm{ppm}$ of $\mathrm{CO}_{2}$ and a photosynthetic photon flux density (PPFD) of 0 , $50,100,300,500,700,1,000$ and $, 1,200 \mu \mathrm{mol} \mathrm{m}^{-2} \mathrm{~s}^{-1}$ in order to verify possible changes in parameters of gas exchange in response to water deficit. Each point in the A $\times$ PPFD curve represents a mean of five replicates for each PPDF.

Experimental design and statistical analysis - The experiment was conducted between September and November 2010 arranged on completely randomized design with five replicates per treatment in each point of analyses. Six points of analyses were carried over these 3 months with a total of 30 plants per treatment. Data of ecophysiological parameters were subjected to variance analysis (ANOVA), and any contrast between means was evaluated by Tukey test at 5\% level of probability, using the statistical package BioEstat 3.0 (Ayres et al. 2000). Normality tests were previously performed. The data were also subjected to Pearson correlation analyses between the parameters evaluated. Correlations were tested by $t$ Student test.

\section{Results and discussion}

The mean air temperature during the experiment was $25.8^{\circ} \mathrm{C}$ with minimum and maximum means of 21 and $31^{\circ} \mathrm{C}$, respectively (Figure 1). Under natural and greenhouse conditions, with increasing radiation, the temperature rises and the relative humidity decreases (Medina et al. 1999) increasing the atmospheric demand for water. So, as expected, we observed a significant inverse correlation between the PAR and RH $(r=-0.705 ; p=0.0229)$, with the lowest mean values of PAR $\left(345.9 \mu \mathrm{mol} \mathrm{m} \mathrm{m}^{-2} \mathrm{~s}^{-1}\right)$ coinciding with the highest mean values of $\mathrm{RH}(57 \%)$, reflecting the influence of high clouds characteristic of this time of year in these meteorological parameters.

Soil moisture $\left(\mathrm{U}_{\text {soil }}\right)$ presented low changes in the pots of control plants with values between 22 to $26 \%$ (Figure 2). However, for pots of plants subjected to 7D and 15D treatments, values ranged between 2 to $12 \%$, and 1 to $8 \%$ respectively, showing statistical differences between these treatments only on the $15^{\text {th }}$ day of the experiment. Notwithstanding the lowest values of $U_{\text {soil }}$ observed coincided with low values of $\mathrm{RH}(57 \%)$ and high values of PAR $\left(405 \mu \mathrm{mol} \mathrm{m}^{-2} \mathrm{~s}^{-1}\right)$ on the $60^{\text {th }}$ day (figure 1). With the returning of daily watering after the $75^{\text {th }}$ day of experiment, in the treatments 7D and 15D until the end of the experiment, the values of $U_{\text {soil }}$ reached $18 \%$ showing no statistical differences when compared to control.

The water treatments of 7D and 15D were sufficient to generate water deficits in plants leading 
to a significant decreasing on leaf water potential ( $\left.\Psi_{w f}, \mathrm{MPa}\right)$ (Figure 3), net carbon assimilation rates (A) (Figure 4), stomatal conductance $\left(\mathrm{g}_{\mathrm{s}}\right)$ (Figure 5) and, transpiration $(E)$ (Figure 6) if compared to control plants. Controls plants did not change significantly in $\Psi_{w f}$, remaining always above $-1.0 \mathrm{MPa}$, showing that daily watering was sufficient to maintain high values of $U_{\text {soil }}$ (Figure 2) and low values of $\Psi_{w f}$ (Figure 3) throughout the whole experiment. On the other hand, the plants in 7D and 15D treatments showed that the $\Psi_{w f}$ values close to -1.0 to $-1.45 \mathrm{MPa}$ at the beginning of the experiment and -2.0 and $-3.0 \mathrm{MPa}$ after 30 days respectively. However, only plants in the 15D treatment showed statistical differences when compared to control in these days.

Aiming to evaluate short-therm responses to re-hydration, the plants of $7 \mathrm{D}$ and $15 \mathrm{D}$ treatments were re-watered 2 days before measurements and sampling at $45^{\text {th }}$ day. Two days after re-watering, plants of 7D and $15 \mathrm{D}$ treatments presented an increasing in $\Psi_{w f}$

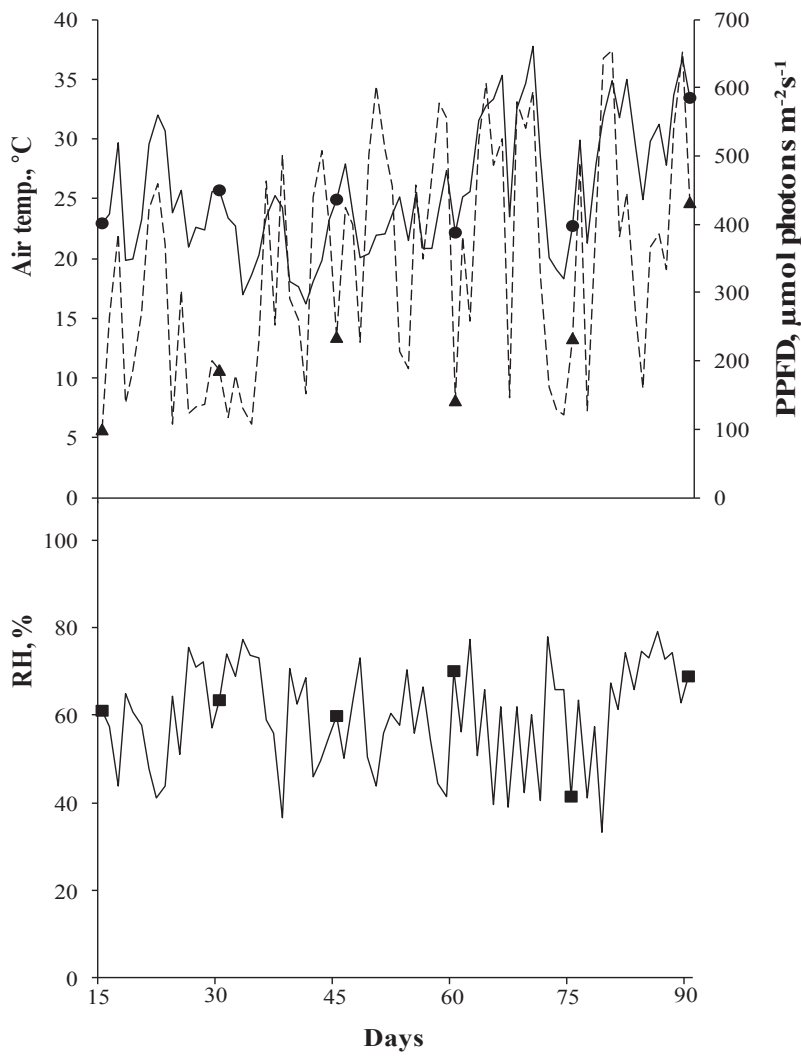

Figure 1 . Air temperature $(\bullet)$, photosynthetically active radiation $(\mathrm{PPFD})(\boldsymbol{\Delta})$, and air relative humidity $(\mathrm{RH})(\boldsymbol{\bullet})$ inside the greenhouse during the experimental period. The symbols indicate the days of ecophysiological evaluations. reaching values of -1.0 and $-1.12 \mathrm{MPa}$ respectively, showing a rapid leaf rehydration. However, at $60^{\text {th }}$ days, treatments 7D and 15D showed a fast decrease in $\Psi_{w f}$ with mean values of -3.3 and -4.3 MPa respectively, with visible effects in $g_{\mathrm{s}}$ (Figure 5) and in $E$ (Figure 6), but keeping positive $A$ values (Figure 4). As expected, there was a positive correlation between variations in $\mathrm{U}_{\text {soil }}$ and in $\Psi_{w f}$ in plants of $7 \mathrm{D}(\mathrm{r}=0.916 ; \mathrm{p}=0.010)$ and $15 \mathrm{D}(\mathrm{r}=0.828 ; \mathrm{p}=0.042)$ treatments, i.e. as soil water availability decreased, the $\Psi_{w f}$ also decreased.

As observed for $\mathrm{U}_{\text {soil }}$, the return of daily watering after 75 days of the experiment, allowed the increase in $\Psi_{w f}$ from plants under water deficit to values similar to the control plants.

The water deficit imposed to the plants in this study was sufficient to generate changes in content and free energy of water in soils and plants, respectively, which in turn affected the photosynthesis of $B$. forficata. In fact, the decrease in water content is accompanied by loss of turgor and wilting, disruption in cell expansion, stomatal closure, reduced photosynthesis, affecting plant growth and productivity (Hu \& Schmidhalter 1998, Kumar \& Sing 1998, Kramer \& Boyer 1995).

Associated to measurements of water potential (Figure 3), net carbon assimilation rates $(A)$ (Figure 4) in response to photosynthetically active radiation (PAR) showed a positive relation of dependency of plants $B$. forficata to soil water availability.

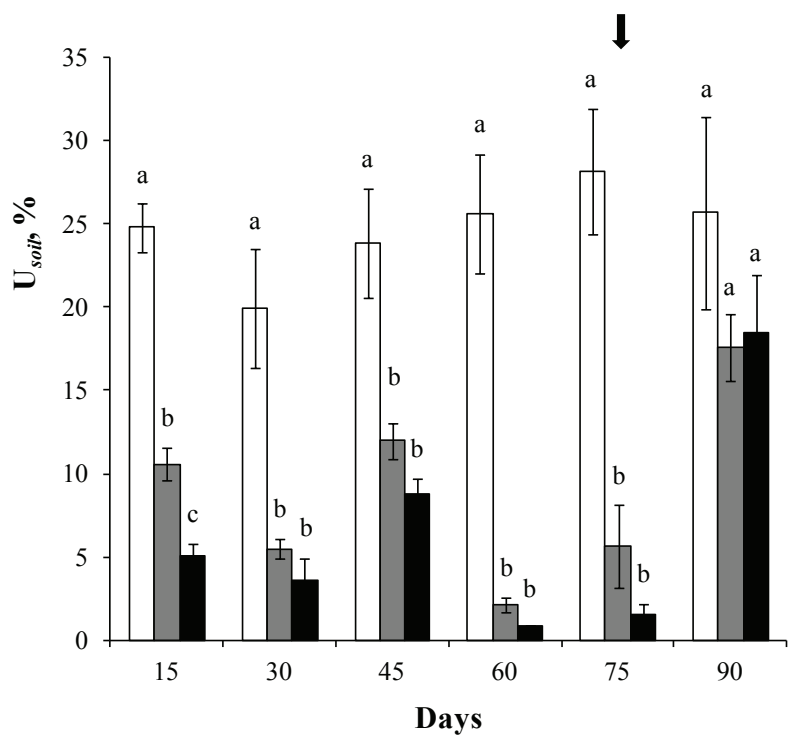

Figure 2. Soil Moisture $\left(\mathrm{U}_{\text {soil }}\right)$ in the pot of plants of Bauhinia forficata Link under daily watered (Control $-\square)$ and watered every 7-(7D - $\square)$ and 15-day (15D - - ) conditions. The arrow indicates the return of daily watering in $7 \mathrm{D}$ and $15 \mathrm{D}$ treatments. Bars indicate the standard error $(n=5)$. Means followed by same letter in each sample do not differ significantly by Tukey's test $(P=0.05)$. 
As observed in figure $4, A$ in $7 \mathrm{D}$ and $15 \mathrm{D}$ treatments was already affected at $15^{\text {th }}$ days of the experiment with values always lower than the control, including negative rates observed on the $30^{\text {th }}$ day of experiment. The re-watering of plants in $7 \mathrm{D}$ and $15 \mathrm{D}$ treatments two days before the $45^{\text {th }}$ days favored the recovering of positive photosynthetic rates returning to zero and negative values at $60^{\text {th }}$ and $75^{\text {th }}$ days of experiment.

During the experiment the higher value of $A_{\max }$ in $B$. forficata was observed in control plants $\left(12 \mu \mathrm{mol} \mathrm{CO} \mathrm{CO}_{2} \mathrm{~m}^{-2} \mathrm{~s}^{-1}\right)$ that showed values always higher than plants of $7 \mathrm{D}$ and $15 \mathrm{D}$ treatments until the $75^{\text {th }}$ day . However, with the return of daily watering, $A_{\max }$ of plants in the 7D and 15D treatments showed values of 7.8 and $9.6 \mu \mathrm{mol} \mathrm{CO} \mathrm{m}^{-2} \mathrm{~s}^{-1}$ respectively at the $90^{\text {th }}$ day, which were significantly higher than control plants $\left(4.7 \mu \mathrm{mol} \mathrm{CO}_{2} \mathrm{~m}^{-2} \mathrm{~s}^{-1}\right)$.

Light and water availability is one of the most important factors that affect the productivity of plants, mainly by reducing stomatal conductance and photosynthesis (Blum 1997). In this work we are showing that the maximum photosynthetic rates $\left(A_{\max }\right)$ of plants under water deficit (Figure 7A) presented a high and significant correlation with $U_{\text {soil }}(\mathrm{r}=0.806$; $\mathrm{p}=0.050$ and $\mathrm{r}=0.846 ; \mathrm{p}=0.034)$ and $\Psi_{w f}(\mathrm{r}=0.887$; $\mathrm{p}=0.018$ and $\mathrm{r}=0.941 ; \mathrm{p}=0.005)$ on the $7 \mathrm{D}$ and $15 \mathrm{D}$

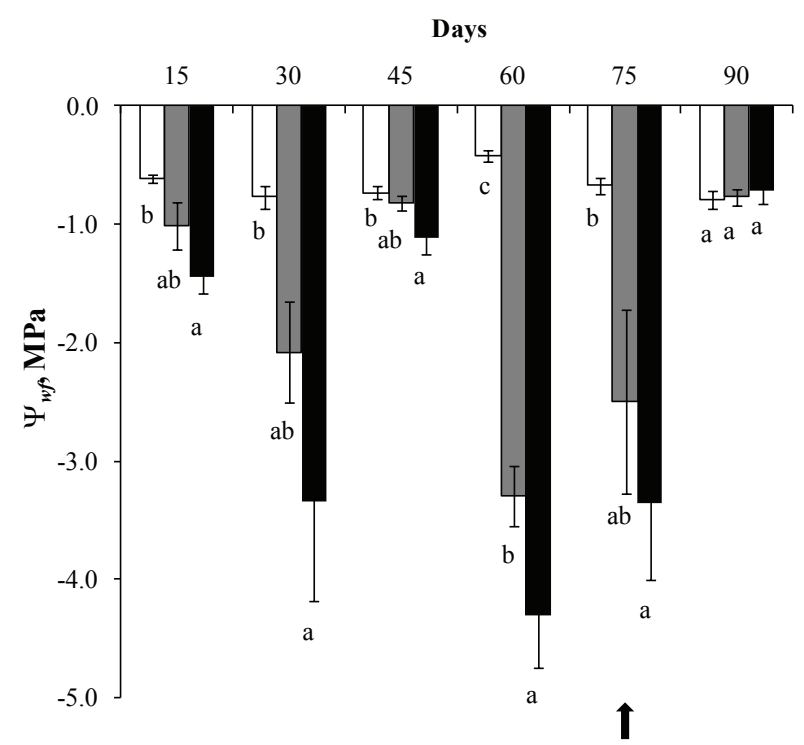

Figure 3. Leaf water potential $\left(\Psi_{w f}\right)$ of plants of Bauhinia forficata Link grown under daily watered (Control - $\square$ ) and watered every 7 (7D - - and 15 day (15D - a) conditions. The arrow indicates the return of daily watering in $7 \mathrm{D}$ and $15 \mathrm{D}$ treatments. Bars indicate the standard error $(n=5)$. Means followed by same letter in each sample do not differ significantly by Tukey's test $(P=0.05)$. treatments respectively. Such correlations associated with the fact that photosynthesis on 7D and 15D plants were higher than control after the return of daily watering reinforces the relation of dependence of photosynthesis of $B$. forficata to water availability, suggesting a high plasticity of its photosynthetic apparatus.

Also with respect to gas exchange, is observed in Figure 4 that the influence of water deficit decreasing $A$ was partly due to reductions in $g_{s}$ preventing, that plants from both 7D and 15D treatments achieved their photosynthetic compensation points. On the other hand, the recovery of positive values of $A$ rates at $90^{\text {th }}$ days in the plants $7 \mathrm{D}$ and $15 \mathrm{D}$ with higher values than the control, associated with the $g_{s}$ data (Figure 5) and $E$ (Figure 6) suggest rapid acclimation of the photosynthetic apparatus of plants 7D and 15D to the low availability of water in the soil and after water recovery.

The process of stomatal aperture and closure is mainly related to light intensity and state of leaf hydration. Thus, in situations of low water availability in soil, plants reduce their stomatal conductance in order to decrease water loss through transpiration, favoring the maintenance of cell turgor in drought conditions (Silva et al. 2004). However, when the stomata closes preventing water loss, simultaneously they restrict the diffusion of atmospheric $\mathrm{CO}_{2}$ for substomatal chambers (Chaves 1991) affecting rubisco carboxylation and the rates of ribulose 1,5 bisphosphate regeneration (Bjorkman 1981), two important factors that define the minimum values of $A$ (Farquhar et al. 1980). Figure 5 shows the stomatal conductance $\left(\mathrm{g}_{\mathrm{s}}\right)$ of $B$. forficata plants submitted to water deficit, where the plants of $7 \mathrm{D}$ and $15 \mathrm{D}$ treatments kept their stomata constantly closed when soil water availability was less than $10 \%$.

Figure 7B also shows that the photosynthetic saturation point (PARsat) was altered in response to water deficit imposed on plants in 7D and 15D treatments. Under optimal conditions of water availability, the PAR sat showed mean values of $665 \mu \mathrm{mol}$ photons $\mathrm{m}^{-2} \mathrm{~s}^{-1}$ in control while the 7D and 15D treatments showed minimum values of 43 and $18 \mu \mathrm{mol}$ photons $\mathrm{m}^{-2} \mathrm{~s}^{-1}$ respectively. In addition, as observed in $A_{\max }$, the PARsat of plants 7D and 15D correlated significantly with $\mathrm{U}_{\text {soil }}(\mathrm{r}=0.775 ; \mathrm{p}=0.050$ and $\mathrm{r}=0.881 ; \mathrm{p}=0.020)$ and $\Psi_{w f}(\mathrm{r}=0.868 ; \mathrm{p}=0.025$ e $r=0.929 ; p=0.007$ ) respectively. 


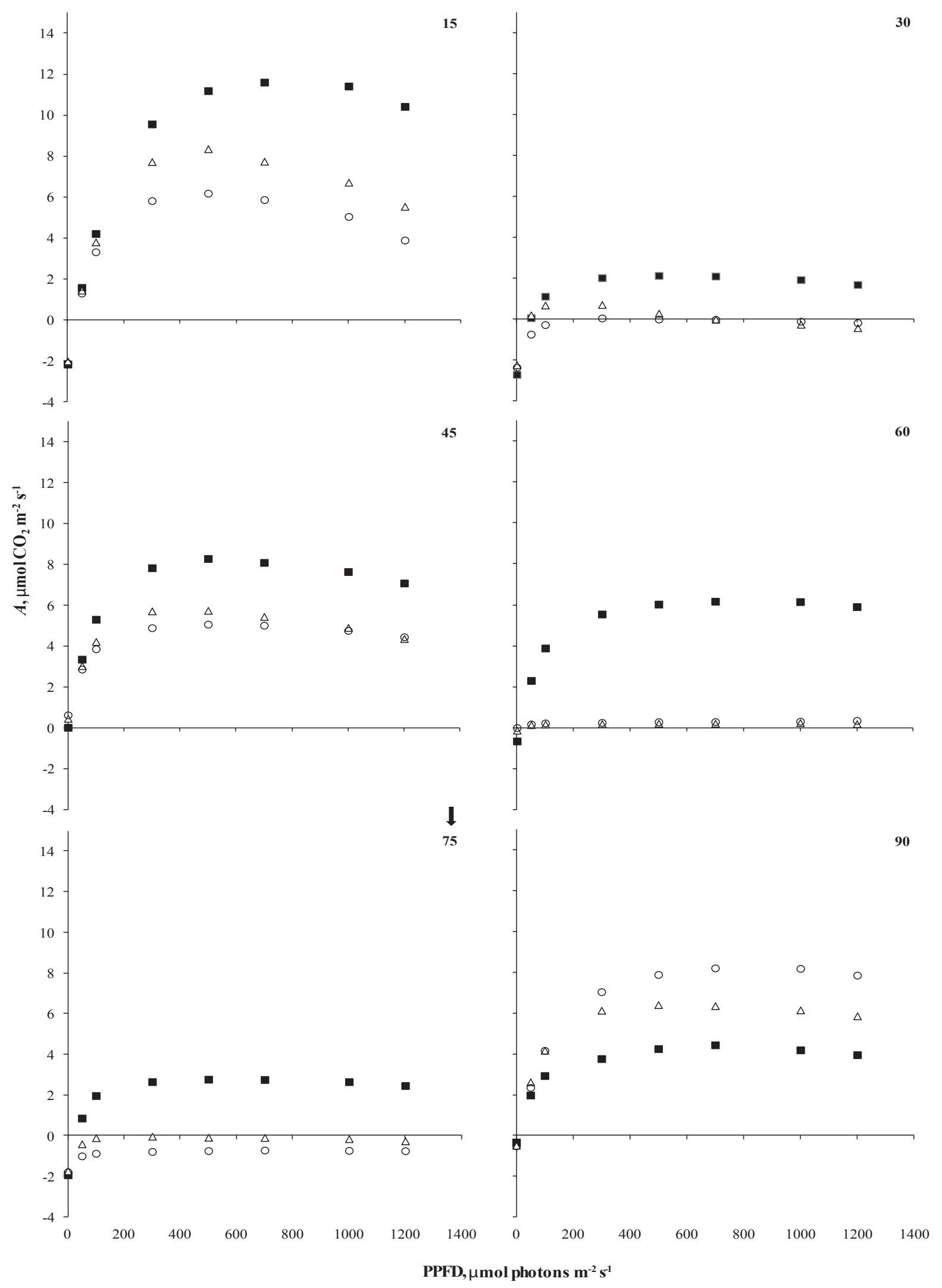

Figure 4. Curves of net carbon assimilation rates in response to photosynthetically active radiation $(A \times$ PPFD $)$ of plants of Bauhinia forficata Link under daily watered (Control - - ) and watered every 7-(7D - $\Delta$ ) and 15-day (15D - 0 ) conditions. The arrow indicates the return of daily watering in $7 \mathrm{D}$ and $15 \mathrm{D}$ treatments $(\mathrm{n}=5)$. 


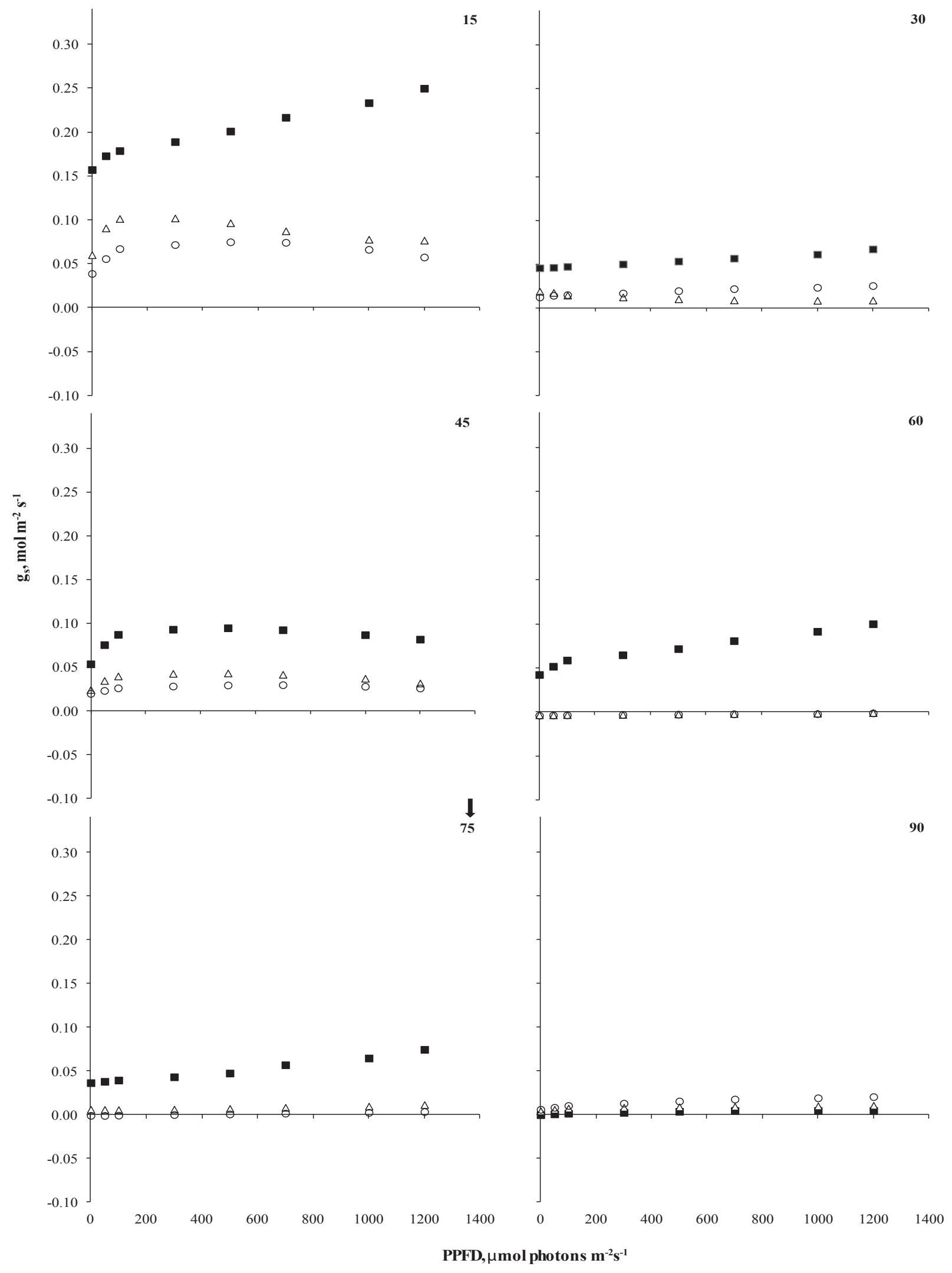

Figure 5. Curves of stomatal conductance $\left(g_{s}\right)$ in response to photosynthetically active radiation $\left(g_{s} x P A R\right)$ of plants of Bauhinia forficata Link under daily watered (Control - - ) and watered every 7-(7D - $\Delta$ ) and 15-day (15D - 0 ) conditions. The arrow indicates the return of daily watering in $7 \mathrm{D}$ and $15 \mathrm{D}$ treatments $(\mathrm{n}=5)$. 


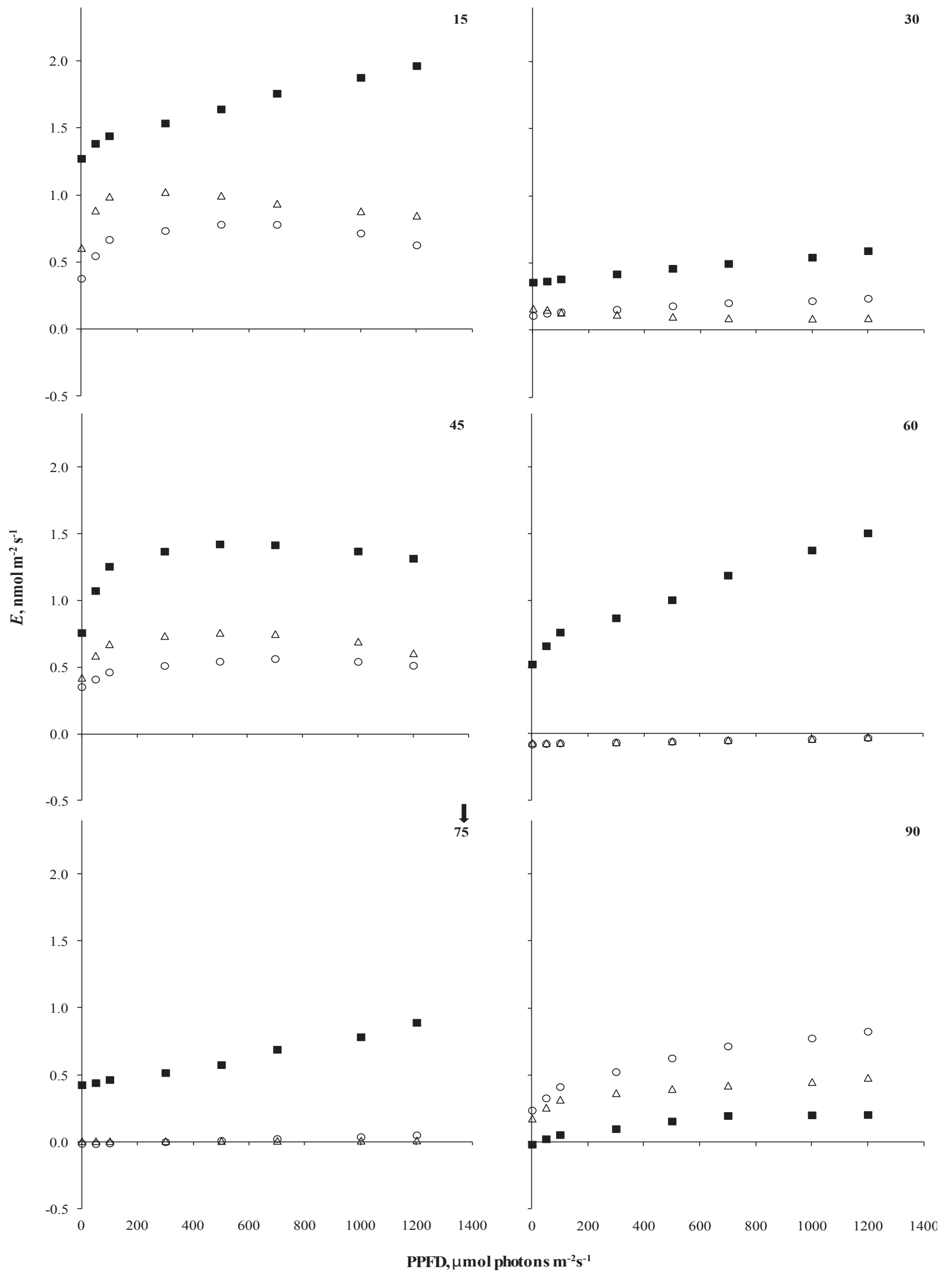

Figure 6. Curves of transpiration $(E)$ in response to photosynthetically active radiation (ExPAR) of plants of Bauhinia forficata Link under daily watered (Control - - ) and watered every 7-(7D - $\Delta$ ) and 15-day (15D - 0 ) conditions. The arrow indicates the return of daily watering in $7 \mathrm{D}$ and $15 \mathrm{D}$ treatments $(\mathrm{n}=5)$. 
The photosynthetic behavior of plants response to water deficit in our experiment are similar to those observed by Portes et al. (2006), who also evaluated under field conditions, the effect of water deficit on photosynthesis of $B$. forficata present in regions of clearing and understory. These authors showed that values of $\Psi_{w f}$ between -2.47 and $-3.3 \mathrm{MPa}$ observed in clearing at the end of the dry season and after 45 days without rain, respectively, characterized a water deficit condition that reduced the photosynthetic rates of plants indicating that this environmental stress significantly affected the use of photosynthetic active radiation by $B$. forficata.

In same way our results showed that photosynthesis of B. forficata, a species that present a broad neotropical distribution is highly dependent of soil water availability. If not otherwise we also confirmed our hypothesis that the species $B$. forficata present a high

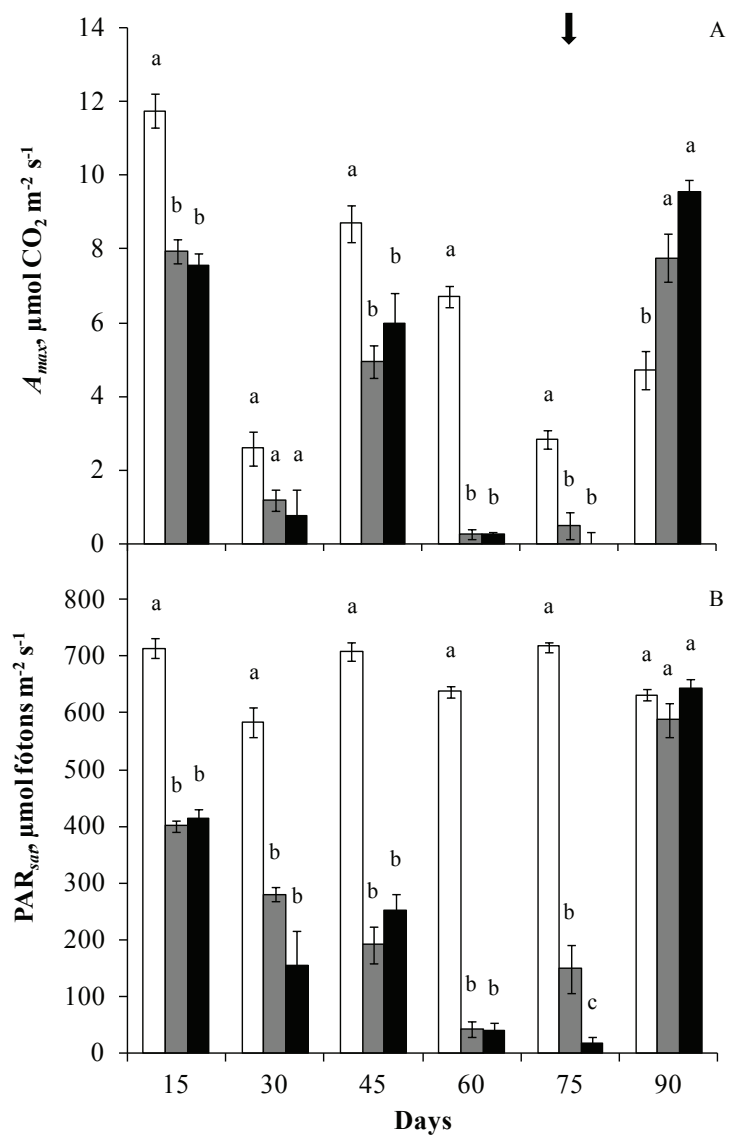

Figure 7 - Maximum net photosynthesis $\left(A_{\max }\right)$ and light saturation point $\left(\mathrm{PAR}_{\text {sat }}\right)$ of plants of Bauhinia forficata Link under daily watered (Control - $\square)$ and watered every 7-(7D - a) and 15-day $(15 \mathrm{D}-\mathbf{m})$ conditions. The arrow indicates the day of daily watering return in 7D and 15D treatments. Bars indicate the standard error $(\mathrm{n}=5)$. Means followed by same letter in each sample do not differ significantly by Tukey's test $(P=0.05)$. capacity to tolerate drought imposed by water deficits of different intensities during early development stage, rapidly recovering photosynthetic rates after the reestablishment of soil water availability. Such aspects should explain the wide territorial occurrence of the species and justify its application in restoration projects of degraded areas. Additional analyses about internal and external control of photosynthesys of B. forficata are necessary to elucidate the physiological and biochemical mechanisms involved in its drought tolerance.

\section{Acknoweledgments}

This work was supported by FAPESP (09/01570-0); R.F.E.S. held scholarship granted by CAPES (Brazil); many thanks are also due to Guto Pereira for their kindly English revision.

\section{Literature cited}

Ayres, M., Ayres J.R., Ayres, D.L.M. \& Santos, A.S. 2003. BioEstat 3.0: aplicações estatísticas nas áreas de ciências biológicas e médicas. Sociedade Civil Mamirauá, Belém, CNPq, Brasília.

Bjorkman, O. Responses to different quantum flux densities. In: O.L. Lange, P.S. Nobel, C.B. Osmond \& H. Ziegler (eds.). Encyclopedia of Plant Physiology: Physiological Plant Ecology I. Springer-Verlag, New York, pp. 57-107.

Blum, A. 1996. Crop responses to drought and the interpretation of adaptation. In: I. Belhassen (ed.). Drought tolerance in higher plants: genetical, physiological and molecular biological analysis. Kluwer Academic Plublishers, Dordrecht, pp. 57-70.

Chaves, M.M. \& Pereira, J.S. 1992. Water stress, $\mathrm{CO}_{2}$ and climate change. Journal of Experimental Botany 43: 1131-1139.

Chaves, M.M. 1991. Effects of water deficits on carbon assimilation. Journal of Experimental Botany 42: 1-16.

Chaves, M.M., Flexas, J. \& Pinheiro, C. 2009. Photosynthesis under drought and salt stress: regulation mechanisms from whole plant to cell. Annals of Botany 103: 551-560.

Clark, R.B. Characterization of phosphatase of intact maize roots. Journal of Agriculture and Food Chemistry 23: 458-460.

Davies, W.J. \& Zhang, J. 1991. Root signals and the regulation of growth and development of plants in drying soil. Annual Review of Plant Physiology and Molecular Biology 42: 55-76. 
Dore, M.H.I. 2005. Climate change and changes in global precipitation patterns: What do we know? Environmental International 31: 1167-1181.

Fan, L., Linker, R., Gepstein, S., Tanimoto, E., Yamamoto, R. \& Neumann, P.M. 2006. Progressive inhibition by water deficit of cell wall extensibility and growth along the elongation zone of maize roots is related to increase lignin metabolism and progressive stellar accumulation of wall phenolics. Plant Physiology 140: 603-612.

Farquhar, G.D., von Caemmerer, S., Berry, J.A. 1980. A biochemical model of photosynthetic $\mathrm{CO}_{2}$ assimilation in leaves of C3 species. Planta 149: 78-90.

Fortunato, R.H. 1986. Revision del genero Bauhinia (Cercideae, Caesalpinioidea, Fabaceae) para La Argentina. Darwiniana 27: 527-557.

Hu, Y. \& Schmidhalter, U. 1998. Spatial distributions of inorganic ions and carbohydrates contributing to osmotic adjustment in the elongating wheat leaf under saline conditions. Australian Journal of Plant Physiology 25: 591-597.

Koslowski, T.T. \& Pallardy, S.G. 1997. Physiology of woody plants. $2^{\text {nd }}$ ed. Academic Press, San Diego.

Kramer, P.J. \& Boyer, J.S. 1995. Water relations of plants and soils. Academic Press, San Diego.
Kumar, A. \& Singh, D.P. 1998. Use of physiological indices as a screening technique for drought to tolerance in oilseed Brassica species. Annals of Botany 81: 413-420.

Long, S.P. \& Hällgren, J.E. 1993. Measurements of $\mathrm{CO}_{2}$ assimilation by plants in the field and laboratory. In: D.O. Hall, J.M.O. Scurlock, H.R. Bolhar-Nordenkampf, R.C. Leegood \& S.P. Long (eds.). Photosynthesis and productivity in a changing environment: a field and laboratory manual. Chapman and Hall, London, pp. 129-167.

Medina, C.L., Machado, E.C. \& Gomes, M.M.A. 1999. Condutância estomática, transpiração e fotossíntese em laranjeira "Valência" sob deficiência hídrica. Revista Brasileira de Fisiologia Vegetal 11: 29-34.

Portes, M.T., Alves, T.H. \& Souza, G.M. 2006. Water deficit affects photosynthetic induction in Bauhinia forficata Link (Fabaceae) and Esenbeckia leiocarpa Engl. (Rutaceae) growing in understorey and gap conditions. Brazilian Journal of Plant Physiology 18: 491-502.

Silva, E.C., Nogueira, R.J.M.C., Neto, A.D.A., Brito, J.Z. \& Cabral, E.L. 2004. Aspectos ecofisiológicos de dez espécies em uma área de caatinga no município de Cabaceiras, Paraíba, Brasil. Iheringia, Série Botânica 59: 201-205. 